\title{
Characteristics of milk production and plasma levels of growth hormone and insulin in Japanese Black cows
}

\author{
H. Shingu ${ }^{1,4}$, K. Hodate ${ }^{2}$, S. Kushibiki ${ }^{1}$, Y. Ueda ${ }^{1}$, E. Touno ${ }^{1}$, \\ M. Shinoda ${ }^{1}$ and S. Ohashi ${ }^{3}$
}

${ }^{1}$ Department of Animal Production and Grasslands Farming, National Agricultural Research Center for Tohoku Region, Morioka, Iwate, 020-0198, Japan

${ }^{2}$ School of Veterinary Medicine and Animal Sciences, Kitasato University

Towada, Aomori, 034-8628, Japan

${ }^{3}$ National Institute of Advanced Industrial Science and Technology

Tsukuba, Ibaraki, 305-8561, Japan

\begin{abstract}
The aim of present study was to examine characteristics of milk yield and secretion of growth hormone $(\mathrm{GH})$ and insulin in Japanese Black cows (beef type) during lactation. (Experiment 1) Milk yield and plasma concentrations of hormones in Japanese Black cows were compared with those in Holstein cows (dairy type). Japanese Black cows had smaller milk yield and secreted less GH but more insulin than Holstein cows. (Experiment 2) Effects of GH-releasing hormone (GHRH) on milk yield and plasma concentrations of hormones in Japanese Black cows were examined. Treatment with GHRH induced increases in milk yield (17.4\%) and in GH and insulin concentrations.
\end{abstract}

KEY WORDS: growth hormone, growth hormone-releasing hormone, insulin, milk yield, cows

\section{INTRODUCTION}

Onset of lactation is accompanied by dramatic changes in hormonal regulation of metabolism. In ruminants, nutrients are preferentially partitioned to the mammary gland for milk production. Nutrient partitioning is regulated by numerous metabolic hormones, among which growth hormone (GH) and insulin are closely related to glucose availability and have a major impact on milk production.

\footnotetext{
${ }^{4}$ Corresponding author: e-mail: shinguu@affrc.go.jp
} 
Growing Japanese Black cattle, beef type, have lower basal plasma GH and higher insulin concentrations than Holstein cattle, dairy type (Matsuzaki et al., 1997; Shingu et al., 2001). In addition to the hormonal profiles, the proportion of GH-expressing cells at the adenohypophysis is smaller in Japanese Black than in Holstein steers (Matsuzaki et al., 2001). Thus, based on the hormonal and morphological profiles during the growing stage, there may be a difference in the secretion of GH and insulin between beef and dairy cows during lactation. The administration of exogenous GHreleasing hormone (GHRH) to dairy cows induces an increase in milk yield, however, in beef cows the effect of consecutive exogenous GHRH treatment on changes in milk yield and metabolic hormones remains unknown.

The objectives of the present study were to examine differences in milk production and basal plasma concentrations of GH and insulin between lactating Japanese Black and Holstein cows (Experiment 1), and changes in these parameters in GHRH-treated Japanese Black cows during lactation, compared with those in saline-treated cows (Experiment 2).

\section{MATERIAL AND METHODS}

The feed was 50:50 forage/concentrate mixture composed of timothy hay, maize silage, lucerne hay cube and concentrate. The cows were provided the feed twice daily $(08.30$ and $16.30 \mathrm{~h})$ and milked twice daily (06.00 and $16.00 \mathrm{~h})$. (Experiment 1) Six Japanese Black cows and seven Holstein cows were used for blood sampling at 2 wk antepartum (AP), 2 or $3 \mathrm{wk}$ and 1, 3 and 6 mo postpartum (PP). (Experiment 2) Ten lactating Japanese Black cows were evenly divided into two groups. Five cows each received a consecutive $21-\mathrm{d}$ treatment from 22 to $42 \mathrm{~d}$ PP with a daily s.c. injection of 3-mg GHRH or saline. The concentrations of plasma GH, insulin, insulin-like growth factor-1 (IGF-1), and NEFA were measured. The data were analysed by ANOVA, Fisher's PLSD post-hoc test (STATVIEW version 5.0, Abicus, CA). All values are expressed as means \pm SEM.

\section{RESULTS}

\section{Experiment 1}

Lactating Japanese Black cows had one-tenth of the milk yield of Holstein cows during 6 mo after calving ( $486.0 \pm 97.0$ vs $4859.2 \pm 163.6 \mathrm{~kg}$; $\mathrm{P}<0.001)$.

Japanese Black cows had significantly lower basal plasma GH and higher basal plasma insulin concentrations than the Holstein cows at all stages (Table 1). In addition, the beef cows had no significant stage-dependent changes in the basal level of either plasma GH or insulin. During early lactation, 3 wk PP, Japanese Black cows had lower NEFA concentrations than Holstein cows $(105.5 \pm 15.4$ vs $226.4 \pm 20.2 \mu \mathrm{Eq} / \mathrm{L} ; \mathrm{P}<0.001)$. 
Table 1. Plasma concentrations of GH and insulin in Japanese Black and Holstein cows

\begin{tabular}{lcclcr}
\hline \multirow{2}{*}{ Stage $^{1}$} & \multicolumn{2}{c}{$\mathrm{GH}^{2}$} & & \multicolumn{2}{c}{ Insulin } \\
\cline { 2 - 3 } \cline { 5 - 6 } & Japanese Black & Holstein & & Japanese Black & Holstein \\
\hline 2 wk AP & $0.90 \pm 0.05^{* 3}$ & $2.30 \pm 0.50$ & & $27.0 \pm 3.6^{* *}$ & $11.6 \pm 1.5$ \\
2 wk PP & $0.81 \pm 0.14^{* *}$ & $9.35 \pm 2.12$ & & $37.3 \pm 8.4^{* *}$ & $6.6 \pm 0.9$ \\
1 mo PP & $0.81 \pm 0.12^{*}$ & $6.53 \pm 2.03$ & & $38.6 \pm 6.1^{* * *}$ & $7.4 \pm 0.9$ \\
3 mo PP & $0.92 \pm 0.16^{* * *}$ & $3.39 \pm 0.47$ & & $46.4 \pm 10.8^{* *}$ & $10.1 \pm 2.0$ \\
6 mo PP & $0.94 \pm 0.07^{* * *}$ & $2.94 \pm 0.32$ & & $43.8 \pm 10.0^{* *}$ & $11.0 \pm 1.6$ \\
\hline
\end{tabular}

${ }^{1} \mathrm{AP}$, antepartum; PP, postpartum

${ }^{2} \mathrm{GH}, \mathrm{ng} / \mathrm{ml}$; insulin, $\mu \mathrm{U} / \mathrm{ml}$

${ }^{3}$ Asterisks indicate significant differences from Holstein cows: $* \mathrm{P}<0.05$; $* * \mathrm{P}<0.01 ; * * * \mathrm{P}<0.001$

\section{Experiment 2}

Mean milk yield was decreased $7.4 \%$ in saline-treated cows compared with that during the 1-wk period before treatment, although treatment with GHRH increased milk yield 17.4\% (Table 2).

Table 2. Changes in relative average milk yield in lactating Japanese Black cows

\begin{tabular}{lccc}
\hline \multirow{2}{*}{ Group } & \multicolumn{3}{c}{ Treatment } \\
\cline { 2 - 4 } & $14-21 \mathrm{~d} \mathrm{PP}^{1}$ & $22-42 \mathrm{~d} \mathrm{PP}$ & $43-49 \mathrm{~d} \mathrm{PP}$ \\
\hline GHRH-treated & $100 . \%^{2}$ & $117.4 \% \%^{* 3}$ & $115.4 \% *$ \\
Saline-treated & $100.0 \%$ & $92.6 \%$ & $83.3 \%$ \\
\hline
\end{tabular}

${ }^{1}$ PP, postpartum

${ }^{2}$ average milk yield for $1 \mathrm{wk}$ before treatment with GHRH or saline was taken as $100.0 \%$

${ }^{3}$ Asterisks indicate significant differences from saline-treated cows: ${ }^{*} \mathrm{P}<0.05$

GHRH-treated cows had higher plasma concentrations of GH, insulin (Table 3), and IGF-1 ( $256.4 \pm 54.3$ vs $76.9 \pm 4.8 \mathrm{ng} / \mathrm{ml} ; \mathrm{P}<0.05)$, than saline-treated cows during the period of treatment. However, there was no significant difference in NEFA levels between GHRH- and saline-treated cows $(109.4 \pm 15.5$ vs $92.3 \pm 12.7 \mu \mathrm{Eq} / \mathrm{L})$.

Table 3. Plasma concentrations of GH and insulin in lactating Japanese Black cows

\begin{tabular}{lllcc}
\hline \multirow{2}{*}{ Group } & & \multicolumn{3}{c}{ Treatment } \\
\cline { 3 - 5 } & & $14-21 \mathrm{~d} \mathrm{PP}^{1}$ & $22-42 \mathrm{~d} \mathrm{PP}$ & $43-49 \mathrm{~d} \mathrm{PP}$ \\
\hline GHRH-treated & $\mathrm{GH}^{2}$ & $0.65 \pm 0.15$ & $1.61 \pm 0.37^{* 3}$ & $0.69 \pm 0.26$ \\
& Insulin & $37.3 \pm 4.1$ & $59.2 \pm 2.4^{*}$ & $42.4 \pm 1.7$ \\
\multirow{2}{*}{ Saline-treated } & & & & \\
& $\mathrm{GH}$ & $0.66 \pm 0.22$ & $0.55 \pm 0.14$ & $0.71 \pm 0.31$ \\
& Insulin & $30.8 \pm 4.9$ & $35.2 \pm 5.3$ & $31.8 \pm 6.2$ \\
\hline
\end{tabular}

${ }^{1} \mathrm{PP}$, postpartum

${ }^{2} \mathrm{GH}, \mathrm{ng} / \mathrm{ml}$; insulin, $\mu \mathrm{U} / \mathrm{ml}$

${ }^{3}$ Asterisks indicate significant differences from saline-treated cows: ${ }^{*} \mathrm{P}<0.05$ 


\section{DISCUSSION}

The present study demonstrates that Japanese Black cows showed lower basal plasma GH concentrations and higher basal plasma insulin concentrations than Holstein cows during lactation. Unlike the improvement in milk production shown by dairy cattle, the emphasis is on meat production for beef cattle, which demonstrates a very small milk yield even during lactation. Numerous previous studies have shown that administration of GH or GHRH to dairy cows induces an increase in milk yield. Treatment with GH also stimulates milk production in beef breeds such as Angus, Charolais, and Simmental (Armstrong et al., 1995). The present study shows that when Japanese Black cows are treated with GHRH, milk yield and endogenous GH, IGF-1 and insulin secretion are increased. However, there was no significant difference in plasma NEFA concentrations between GHRH- and saline-treated beef cows. From the present results, treatment with GHRH increases milk yield, although lipid mobilization for milk production might be weak even during the lactation period.

\section{CONCLUSIONS}

Lactating Japanese Black cows (beef type) have much smaller milk yield and secrete less GH but more insulin than Holstein cows (dairy type), suggesting that the beef cattle maintain a strong anabolic status even during lactation. Treatment with GHRH to Japanese Black cows induces increased milk production as well as secretion of GH, IGF-1 and insulin, but no significant changes in plasma NEFA levels, suggesting that lipid mobilization for milk production might be weak even during lactation.

\section{REFERENCES}

Armstrong J.D., Harvey R.W., Poore M.A., Simpson R.B., Miller D.C., Gregory G.M., Hartnell G.F., 1995. Recombinant bovine somatotropin increases milk yield and calf gain in diverse breeds of beef cattle: associated changes in hormones and indices of metabolism. J. Anim. Sci. 73, 3051-3061

Matsuzaki M., Takizawa S., Ogawa M., 1997. Plasma insulin, metabolite concentrations, and carcass characteristics of Japanese Black, Japanese Brown, and Holstein steers. J. Anim. Sci. $75,3287-3293$

Matsuzaki M., Sato T., Morita S., Shiba N., Tsuneishi E., Hara S., Ozutsumi K., Yamaguchi T., 2001. Pulsatile growth hormone secretion, circulating insulin-like growth factor-1 concentration and cellular density of somatotrophs differ between Wagyu and Holstein steers. Anim. Sci. 73, 425-432

Shingu H., Hodate K., Kushibiki S., Ueda Y., Watanabe A., Shinoda M., Matsumoto M., 2001. Profiles of growth hormone and insulin secretion, and glucose response to insulin in growing Japanese Black heifers (beef type): comparison with Holstein heifers (dairy type). Comp. Biochem. Physiol. Pt. C 130, 259-270 